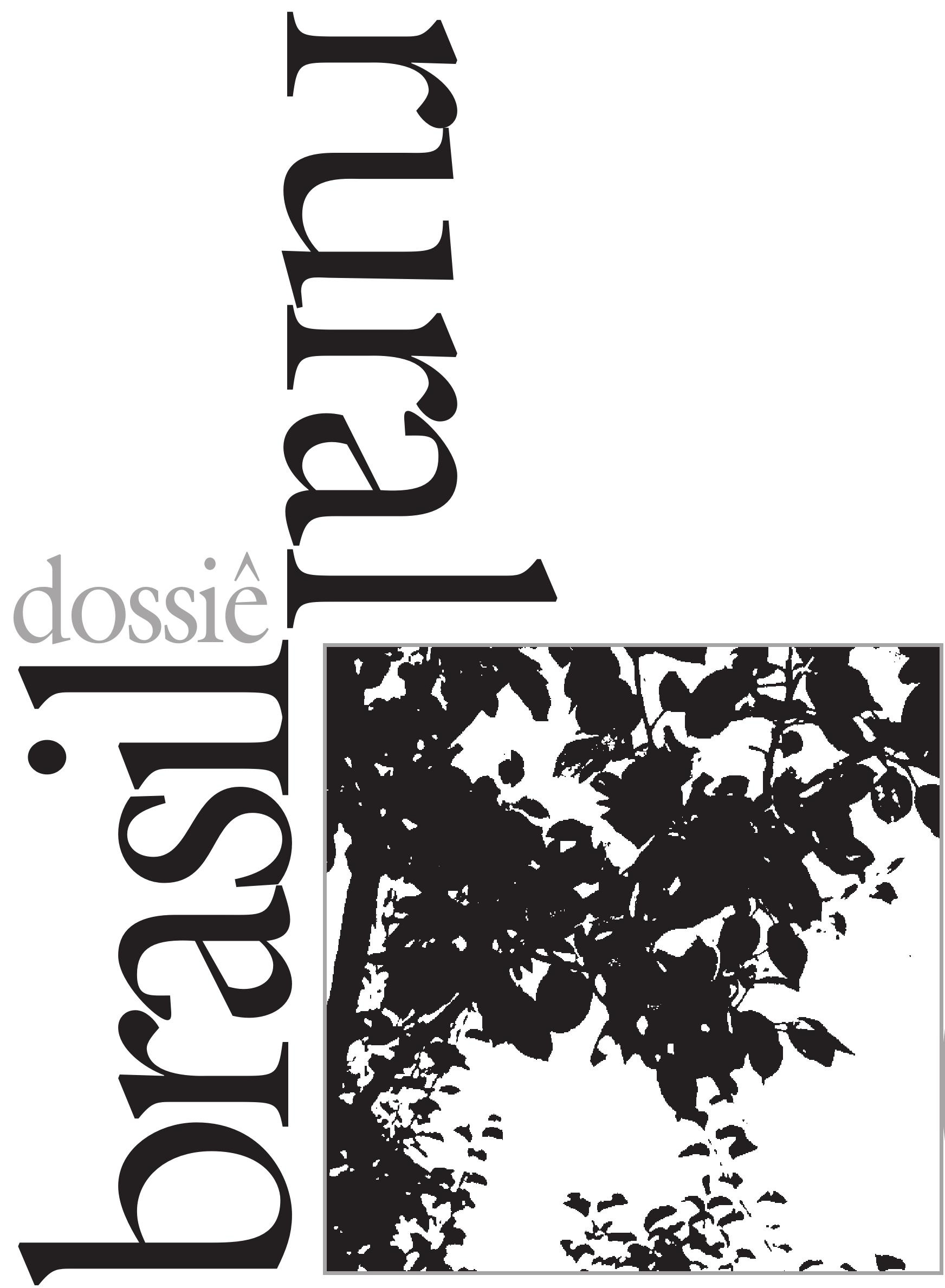


“Mas há um programa na TV Globo

nos domingos, o 'Globo Rural', que

acho extremamente interessante,

porque ensina uma porção de coisas"

(Carlos Drummond de Andrade,

in Jornal do Brasil).

O presente artigo é amplamente baseado em: DeMãos Dadas com - Mundo Rural, trabalho de conclusão de curso, São Paulo, ECA

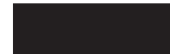

\section{5 anos de}

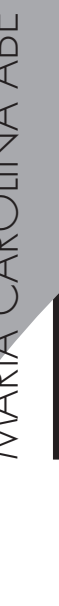

\section{máos dadas com}

O Globo Ruval comemora suas bodas de prata. A trajetória teve início em 6 de janeiro de 1980, quando o departamento de jornalismo da Rede Globo lançou seu novo programa atendendo a uma encomenda do departamento de MARIA CAROLINA ABE é jornalista formada pela Escola de Comunicações e Artes da USP. marketing e comercialização, que vislumbrara espaço na programação para um produto voltado para o campo. 


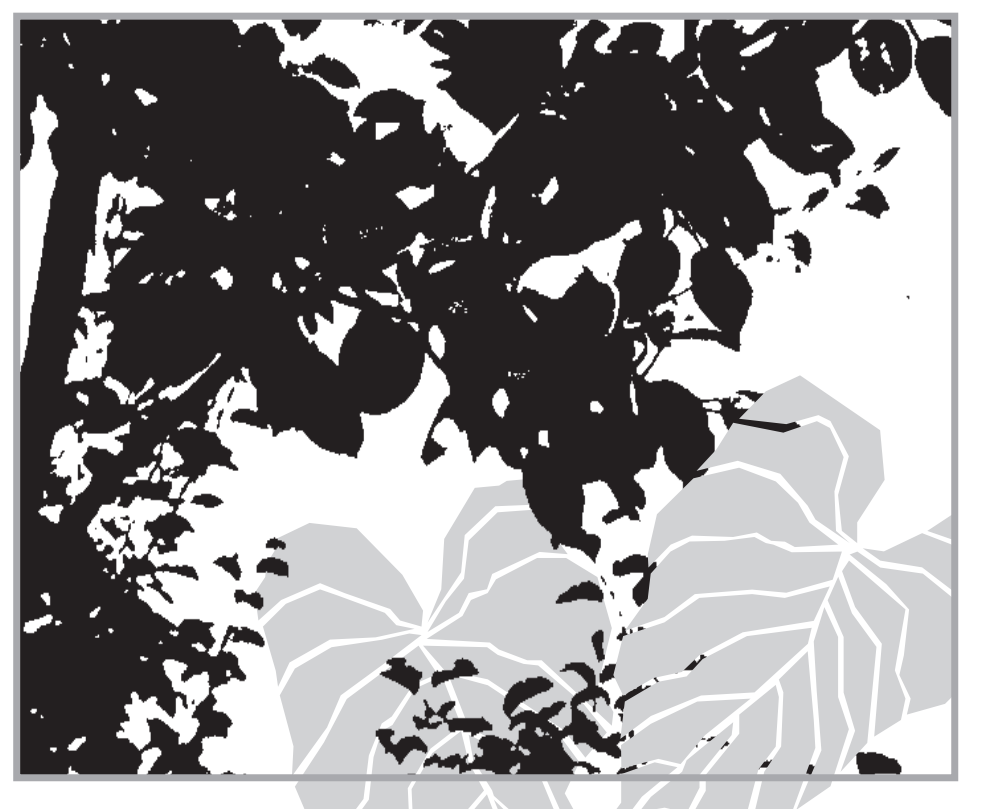

Na conjuntura do "milagre brasileiro", havia grande alvoroço nos campos, que envolvia tanto a chegada maciça da eletricidade e da televisão à zona rural, quanto mudanças na agricultura, com a expansão das fronteiras agrícolas nacionais para a Amazônia e o Centro-Oeste e o aumento das exportações.

Outra transformação foi o intenso processo de industrialização da agricultura com a introdução de bens, máquinas e insumos no setor agropecuário e, a partir da década de 60, a chegada ao país de indústrias de tratores, fertilizantes, defensivos, etc. O meio rural passou a ser um novo mercado consumidor e, portanto, alvo de anúncios publicitários.

Por um lado, com a televisão chegando até o homem do campo, havia uma demanda de público. Por outro, com o desenvolvimento de uma indústria de insumos modernos, havia também uma demanda de anunciantes. Nesse cenário, foi lançada a semente do Globo Rural, cuja primeira reportagem abordou, justamente, a nova agricultura do cerrado, fruto da expansão das fronteiras agrícolas .

O sucesso foi tanto que, após seis meses no ar, passou de meia hora para uma hora de duração, tempo que mantém até hoje, sempre aos domingos. Além disso, como o mercado do rural continuava aquecido, a emissora criou mais um programa para abri- gar a fila de anunciantes: o Som Brasil (1).

Com isso, o Globo Rural foi antecipado das 10 para as 9 horas. Algum tempo depois, passou para as $8 \mathrm{~h} 30 \mathrm{e}$, depois, para as 8 horas, hora em que é exibido atualmente em rede nacional.

O programa garante boa média de pontos no Ibope e de share, a participação porcentual entre os televisores que estão ligados naquele horário. Em 2003, alcançou uma média de 12 pontos de audiência e $60 \%$ de share. Em todo o país, de acordo com dados da Superintendência Comercial da Rede Globo (2), cada edição é vista por mais de 7,7 milhões de telespectadores, dos quais 3,6 milhões são das classes ABC e têm mais de 25 anos - bom público para os anunciantes.

Segundo o chefe de reportagem, Lucas Battaglin, o Globo Rural sempre deu mais audiência do que se esperava dele e sempre a manteve muito estável. Além disso, ao contrário do que costuma ocorrer com outros telejornais, quanto menor a cidade, maior sua audiência.E o programa não atinge somente o homem do campo. Exemplo disso é a cidade de São Paulo, onde a média se mantém em 12 pontos de audiência e $56 \%$ de share.

Aos 25 anos, o Globo Rural se consagra como um dos mais sólidos modelos de jornalismo televisivo e também um dos mais premiados programas de mídia. As paredes da sua redação são forradas com molduras que ostentam prêmios e menções honrosas concedidos por instituições da área rural e de mídia, junto com uma série de homenagens em diplomas, troféus, medalhas e placas, concedidos, por exemplo, pela Embrapa, por universidades, por cidades e estados.

É bastante lembrado por jornalistas como um dos poucos programas de qualidade da TV brasileira, um modelo bemsucedido de telejornalismo, um programa que valoriza a reportagem e um espaço de divulgação científica. Dentro da Central Globo de Jornalismo, é tido como um dos programas top de linha, junto com dois outros ainda mais velhinhos: Fantástico e Globo Repórter, no ar desde 1973. 


\section{DE MÃOS DADAS COM O MUNDO RURAL}

Bem noalto da serra de Santana, no vale do Rio Jaguaribe, sertão do Ceará, nascia em 5 de março de 1909 um agricultor da “terra sempre mais extinta": Antônio Gonçalves da Silva, conhecido como Patativa do Assaré. Lavrou com muita destreza as terras secas e as letras férteis. Como muitos de seus, pouco foi à escola. Mas diferente dos outros, ele tinha um dom de nascença: o dom de fazer versos. Fazer versos sobre tudo o que pensava, sobre tudo o que sentia e sobre tudo o que queria.

Fez poesia social, poesia de crítica política, poesia autobiográfica e até poesia que virou música - comoos versos de "Triste Partida", que fizeram sucesso na voz de Luiz Gonzaga. Patativa se auto-intitulou "poeta da roça", como explica em tex to homônimo:

"Sou fio das mata, cantô da mão grossa, Trabaio na roça, de inverno e de estio. A minha choupana é tapada de barro, Só fumo cigarro de paia de mío.

[...]

Não tenho sabença, pois nunca estudei, Apenas eu sei o meu nome assiná.

Meu pai, coitadinho! vivia sem cobre,

E o fio do pobre não pode estudá.

[...]

Meu verso rastêro, singelo e sem graça, Não entra na praça, no rico salão, Meu verso só entra no campo e na roça Nas pobre paioça, da serra ao sertão".

Grande poeta popular brasileiro, chegou a ser comparado a João Cabral de Melo Neto, Casimiro de Abreu, Gonçalves Dias e Castro Alves. Pessoa tão simples, mas ao mesmo tempo tão rica, acabou conquistando fãs pelo Nordeste e despertando o interesse de pesquisadores e também da imprensa.

Em uma das entrevistas que deu à TV, já com 90 anos, aparece o matuto boa parte do tempo andando de mãos dadas com a repórter. Repórter essa que guia seus passos de homem que quase não enxerga mais . Repórter que, gentilmente, acompanha seu caminhar dificultoso que se apóia na bengala, pelo solo de terra da serra de Santana ou pelas ruas de paralelepípedo onde fica a feira. As mãos dadas. Os passos num compasso. Risadas. Epifania. Ela é Ana Dalla Pria, repórter do Globo Rural. A reportagem foi exibida em três blocos no programa de 21 de março de 1999.

Não é o tempo de duração que faz dessa uma grande-reportagem. O ponto-chave é a emoção que desperta o personagem,com sua história de vida, com sua forma ímpar de ver o mundo e de se relacionar com as pessoas, com sua expressão, sua oralidade, sua criatividade, sua rica cultura popular e sábios ensinamentos; além da forma como repórter e entrevistado entram em comunhão e caminham juntos, conduzindo a narrativa de forma contextualizada, intensa, complexa. “A comunicação social só em momentos luminosos atinge a comunhão poética, embora os autores busquem a eficiência da legibilidade. Falta à narrativa regida por fórmulas o toque mágico da 'comunicação humana'” (3).

A repórter andando de mãos dadas com Patativa do Assaré, os versos e a história de vida do poeta da roça são coisas que despertam muita emoção em quem assiste à reportagem. Mexe com nossa sensibilidade de uma forma espontânea, natural, fluida, bonita. Não é piegas, tampouco sensacionalista. $\mathrm{O}$ que faz a principal diferença no Globo Rural é essa relação que ele consegue estabelecer, de um lado, com os personagens entrevistados e, de outro, com o público telespectador.

É uma relação de comunicação plena, quase uma comunhão, que transborda o esquema emissor-mensagem-receptor, as tradicionais estruturas jornalísticas de gancho, lead e pirâmide invertida ou os ultrapassados conceitos de objetividade, distanciamento, razão e verdade. É reflexo da passagem da entrevista para o diálogo. “A carga emocional da interação social criadora vai desaguar na matéria editada com esse tom maior que fica visível, audível, e
3 Cremilda Medina, A Arte de Tecer o Presente: Narrativa e Cotidiano, São Paulo, Summus, 2003 , p. 85 
será socializado através da plena identificação: o leitor, telespectador, ouvinte 'comunga' com essa relação total, entra nela pela magia da linguagem simbólica que substitui o ato da entrevista" (4).

Provas disso são, no caso dos entrevistados, a completude com que se entregam na gravação, sorrindo, chorando, mostrando a casa, a família, as receitas, os problemas e até os segredos; e, no caso dos telespectadores, as cartas que enviam à redação, nas quais demonstram se sentir amigos, íntimos, parte da família do Globo Rural:

"Hoje Globo rural vocês continua inspirando o mesmo sentimento de carinho, sem dúvida está para sempre no coração dos brasileiros" (MVS, Lauro de Freitas/BA).

"Vocês são uma equipe familia que nunca pode deixar de exestir mesmo que o mundo seja robótico" (MSM, Lorena/SP) (5).

O mundo robótico é o mundo dos velhos paradigmas do Ocidente. O mundo que só aceita o científico. O mundo que vê religião, mitos, lendas, superstições e todo tipo de crença popular como tolices. O mundo que exclui aqueles que não falam de acordo com as normas cultas gramaticais. O mundo que só apresenta problemas e não propõe soluções. O mundo onde os versos de Patativa do Assaré não têm valor nenhum como literatura. O mundo onde o jornalista não pode se emocionar com a situação que vivencia. O mundo onde o jornalista não pode dar as mãos ao entrevistado.

Patativa do Assaré andou de mãos dadas com a repórter Ana Dalla Pria. Esse é um ato tão simbólico. Conota a comunhão, o encontro, a entrega, a cumplicidade, a confiança. Patativa confia em Ana e lhe deixa guiar seus passos. Patativa se mostra como realmente é e deixa que Ana conduza a reportagem. Isso é o que o filósofo Martin Buber considera ser um diálogo que atinge a interação humana criadora, quando "ambos os partícipes do jogo da entrevista interagem, se modificam, se revelam, crescem no conhecimento do mundo e deles próprios" (6).
Desde o começo, o Globo Rural é composto essencialmente por reportagens, gravadas em todo o território nacional. Infelizmente, não pude acompanhar o trabalho de campo do programa. Apenas acompanhei por duas semanas o trabalho da equipe na redação em São Paulo, que inclui reuniões de pauta, produção e edição de matérias, gravações em estúdio, reuniões de avaliação do programa e encaminhamento das respostas das cartas do público. Além, é claro, de ter assistido a uma porção de reportagens que foram ao ar. A partir dessa observação e desse material foi possível perceber que existe intensidade e sensibilidade na realização do trabalho - na leitura de cada carta que chega à redação, na preocupação detalhista de como trabalhar cada assunto e cada personagem dentro da matéria, no resultado que vemos a cada domingo.

"O que em qualquer reportagem se torna um elemento marcante é a relação intensa que você tem com a rua e, normalmente, com as pessoas que compõem a reportagem que você vai fazer. É você estar absolutamente inteiro ali pra captar o que aquela pessoa tem pra te oferecer...não pra você, mas pro público que está atrás de você vendo", explica o chefe de reportagem, Lucas Battaglin.

Para ter essa relação intensa com a rua é preciso, primeiramente, abandonar a clausura da redação, a comodidade das rotinas profissionais, as fórmulas rígidas e limitantes, para ir ao mundo viver o cotidiano, interagir com o contexto social, encontrar-se com a vivacidade dos personagens. O repórter do Globo Rural não tem um olhar burocrático perante a realidade e se lança absolutamente aberto a essa relação. O resultado é uma narrativa tensa e densa, uma grande-reportagem, independentemente de seu tamanho.

O programa não sai a campo para comprovar uma tese ou pegar "umas aspas", como se diz no jornalismo. Está aberto para perguntar, ouvir, descobrir, se encantar. É só no trabalho de campo e no contato com a realidade que sente quanto a matéria vai render, que encontra alguns 
personagens e intui qual o tamanho deles dentro da matéria e com que ângulo eles irão participar da história. Também é uma equipe que precisa estar aberta para mudar o rumo da pauta e também para enxergar novas pautas.

O repórter Vico Iasi conta que, enquanto fazia matérias pelo Nordeste, reparou nas crianças que viviam penduradas nas saias das mães e pensou: se a seca afeta tanto a vida dos homens e mulheres, como será que muda a vida das crianças? Daí bolou uma pauta: a vida das crianças do sertão no período da seca. Já a repórter e apresentadora Helen Martins foi a um assentamento de reforma agrária para gravar uma matéria sobre o cultivo de hortaliças e depois de ouvir as pessoas do local, decidiu ampliar a pauta e fez uma grande-reportagem sobre os programas de reforma agrária, na qual o cultivo de hortaliças é apenas um trecho.

Ao contrário do que algumas pessoas pensam, o Globo Rural nãoé um programa especializado, agrotécnico, de assessoria técnica ou extensão rural, mas sim um telejornal voltado de costas para o concreto das cidades, olhando para o mundo rural em seus diversos aspectos - política, economia, transportes, educação, problemas sociais, trabalho, legislação, meio ambiente, saúde, etc. Também têm lugar a cultura e o imaginário do homem rural, em matérias sobre música, arte, literatura, lendas e superstições. Outro tema constanteé o meio ambiente, já que é nas propriedades rurais que está a maior parte do verde e das nascentes de água.

O universo de abordagem do programa é o mundo rural e o homem rural - que de certa forma, ainda são um pouco mais puros e singelos e mantêm uma forte ligação com a tradição oral, a cultura e o conhecimento populares. "Hoje o homem do campo mistura a sua experiência meteorológica adquirida com os seus antepassados, com as informações do Centro de Tecnologia Aeroespacial (CTA), transmitidas diariamente no programa Bom Dia Brasil e nos noticiários das rádios, dando a previsão do tempo" (7).
É um espectro de abordagem amplo e que, definitivamente, não cabe dentro do rigor científico e da objetividade racionalista. O Globo Rural transita com muita destreza e beleza entre os saberes científicos acadêmicos, a sabedoria popular, as narrativas míticas e as diferentes culturas, sabendo valorizar a importância de cada coisa: as plantas utilizadas pelos índios como remédios, as técnicas caseiras para ver se vai chover no Nordeste, as crenças e superstições acerca do eclipse da lua, as pesquisas e descobertas científicas.

As narrativas tecidas são complexas e não há linearidade nem fragmentação narrativa. O jornalista analisa a pauta sob diferentes ângulos e aprofunda os conteúdos informativos no tempo e no espaço: no presente, insere-a no contexto que a cerca, cita fatos complementares; busca reconstituir as raízes históricas e as origens do fato por meio de pesquisa; ouve a opinião especializada por meio das entrevistas; propõe as perspectivas para o futuro; procura chegar à universalização a partir da individualização do fato social, da humanização do assunto.

A repórter Helen Martins cita o exemplo da matéria que fez sobre uma técnica que usa a fermentação da palma forrageira para torná-la mais rica em proteínas para alimentação do gado. Chegando a Alagoas, descobriu que a cidade de Palmeira dos Índios tivera como prefeito um ilustre escritor, Graciliano Ramos, autor do livro $\mathrm{Vi}$ das Secas, que conta um drama da seca no sertão. De volta a São Paulo, leu o livro e assistiu ao filme Vidas Secas. Na matéria, elencou todos esses elementos: Vidas Secas, o sertão, a palma, suas origens e a técnica de enriquecimento para alimentar o gado. "Isso é o que dá o charme, é o molho da matéria." O mesmo assunto poderia ter sido abordado de um jeito bem mais simplista, mas certamente não teria o mesmo resultado: "Todo o charme da matéria vai embora: Graciliano, filme, tudo. Posso tirar tudo isso. Precisa disso pra contar a técnica? Não. Mas, se você quiser mostrar a realidade daquela bacia leiteira ali, você tem que abrir".
Osvaldo Meira Trigueiro, A TV Globo em Duas Comunidades Rurais da Paraíba: um Estudo sobre a Audiência da Televsão em Determinados Grupos Sociais, dissertação de mes trado, Recife, Universidade Fe deral Rural de Pernambuco 1987 , p. 33 
Dois fatores que contribuem para o primor do resultado são o tempo de duração dessas reportagens, possibilitando ao repórter/editor inserir elementos que, em uma matéria curta, seriam descartados ("o molho da matéria"); e o tempo de que esse repórter/editor dispõe para trabalhar no campo e na redação, o que permite um mergulho no assunto, um contato maior com aquela determinada realidade, uma pesquisa mais aprofundada e, às vezes, até voltar ao local para gravar o que ficou faltando.

Outro ponto importante é que os repórteres do Globo Rural editam suas próprias matérias, diferente do que ocorre nos outros telejornais da Globo. A vantagem é que eles estiveram in loco, vivenciaram as situações, estiveram cara a cara com os personagens e sabem o porquê de cada imagem.

O programa tem uma linha mestra editorial, uma linguagem tradicional, mas cada repórter acrescenta um pouco de seu estilo, de seu jeito de contar a história. Essa liberdade de autoria é até incentivada pela chefia do programa. Segundo Battaglin, quando uma equipe vai para o trabalho de campo,é discutido antes o que deve ser abordado, mas o como deve ser abordado depende de cada profissional.

Um exemplo são as matérias cantadas do repórter e apresentador Nelson Araújo, que substituiu o tradicional texto em off do jornalista por versos em redondilha, semelhantes aos de literatura de cordel, de onde tirou sua inspiração. A primeira experiência foi em uma grande-reportagem sobre o pequi: “O que é, o que é? É verde por fora, amarelo por dentro, perigoso no meio, branco no centro?".

Essa liberdade de autoria e estilo facilita a construção do narrador, que foge à fórmula trivial. O repórter divide a narração da história com os personagens e está articulado com as informações, o ambiente e as falas dos personagens. É um narrador que se movimenta dentro da cena, junto comos outros protagonistas, mostrando que "pertencemos à saga do outro e o outro se movimenta na nossa própria aventura. Perde-se então a pretensão do signo do distan- ciamento e a interação dos afetos constitui o signo da relação" (8).

Justamente por isso, algumas vezes o repórter se sente à vontade para deixar de lado o narrador em terceira pessoa distanciado e se colocar, com toda sua subjetividade, como participante da cena, que está em contato com os personagens, que anda de mãos dadas com o personagem, que prova da receita do doce de leite, que sente o fedor das águas poluídas de um rio, que tenta quebrar o coco do babaçu com o machado, que ri, se encanta, se surpreende, se espanta, se emociona, fica indignado.

De forma geral, o tex to dos repórteres e apresentadores conta com o mesmo princípio de oralidade, simplicidade e ordem direta das frases, requisitos de um bom texto de TV, porém consegue ganhar ainda mais simplicidade, leveza, fluência, cadência, poesia até, além de incluir o sotaque caipira de alguns dos repórteres - como José Hamilton Ribeiro -, expressões típicas do homem do campo e vocabulários diferentes de todo o Brasil, podendo valorizar a riqueza nacional dos "modos de dizer" e expressões.

Com relação à linguagem visual, adaptada ao horário de exibição e à temática do programa, merecem destaque o ritmo mais pausado da câmera e da edição, o uso constante do plano-seqüência (9), quase todas as imagens e entrevistas gravadas durante o dia e em ambiente externo e os apresentadores e repórteres deixando de lado o terno e a gravata.

No geral, o programa também tem todos os cuidados normais de qualquer jornalismo sério: ouvir as diferentes opiniões, confirmar as informações, responder às informações básicas sobre o assunto, cobrir todo o território nacional de forma equânime, etc. O que vale destacar é que o Globo Rural tem um cuidado muito grande com pequenos detalhes, quase que um preciosismo: a discussão da colocação de cada elemento na matéria, a precisão de cada palavra escolhida, a discussão exaustiva dos assuntos polêmicos, a presença dos consultores especializados (o médico veterinário e professor da USP Enrico Ortolani e 
o agrônomo e professor da Unesp de Botucatu Chukichi Kurozawa) para evitar erros técnicos, a realização de pré-entrevistas por telefone antes das entrevistas, a realização de reuniões de avaliação antes (apelidada de "vídeo-show") e depois da exibição do programa.

Essa reunião chamada de "vídeo-show", que ocorre todas as quartas-feiras, é uma peculiaridade do Globo Rural. A equipe assiste às matérias, avalia, debate, antes de elas irem ao ar no domingo. É o momento de verificar e corrigir quaisquer erros em questões técnicas e de discutir a reportagem e a edição - a clareza e precisão das informações e das palavras escolhidas para transmiti-las, se falta alguma informação importante, se a sequiência da edição está compondo uma boa narrativa, etc. Funciona como um controle de qualidade do programa, no qual se coloca uma massa crítica em cima do trabalho, tendo um respeito pela opção narrativa de cada repórter e, principalmente, um respeito pelo telespectador, que deve receber as informações corretas e de uma forma clara, explica Battaglin.

Mas é jornalismo e o resultado que vai ao ar nunca é $100 \%$ satisfatório. Por isso, toda segunda-feira ocorre uma nova reunião para comentar o programa que acabou de ser exibido. Essa reunião pós-jornal começou no Globo Rural e já está instituída em todos os telejornais da Globo. Para Battaglin, apesar de não ser possível mudar o que já foi ao ar, é possível melhorar o processo. "Você pode mexer na cabeça das pessoas que farão o jornal no dia seguinte e construir uma riqueza de pensamento para fazer esse produto de uma maneira mais correta, mais eficiente."

Fugindo da média do jornalismo atual, o Globo Rural não só exibe os problemas do país como também procura mostrar possíveis soluções. O programa assume o grande papel de agente cultural, de renovar, alterar e até revolucionar o estabelecido. Segundo Vico Iasi, quando o programa aborda um problema ou uma dura realidade social, procura "não ficar no determinismo de que 'é assim que tem que ser' e mostrar que é possível trabalhar com pro- jetos pra mudar essas realidades". São matérias geralmente exibidas em séries, com a primeira trazendo o problema e a segunda, uma experiência que deu certo, uma "solução".

Um exemplo é a série sobre as quebradeiras de coco do babaçu no Maranhão, de Helen Martins. A primeira reportagem fala sobre as mulheres que vivem numa pior situação de trabalho, com trabalho duro e renda baixíssima. Já a segunda mostra a experiência de uma comunidade que formou uma associação e, organizada, passou a fazer produtos de maior valor agregado, aumentando a renda e a qualidade de vida da população.

Outro exemplo é a série sobre escolas rurais, do repórter César Dassie. A primeira reportagem fala da diminuição no número de escolas na zona rural, da falta de transporte, da dificuldade que alguns alunos enfrentam para chegar até a escola, mas também dos sonhos dessas crianças. A segunda mostra a escola Fundamar, na zona rural de Minas Gerais, um projeto que procura oferecer ensino, cultura e alimentação de qualidade para as crianças da região.

Um último exemplo é a série do repórter Vico Iasi sobre a Amazônia. Se uma matéria mostrou como o desmatamento tem transformado a floresta tropical em pasto para a pecuária, outra falou de dois projetos: uma empresa estrangeira que explora as madeiras de forma sustentável e uma pequena comunidade que aumenta a renda familiar recolhendo e vendendo as sementes da mata, em parceria com a Universidade Federal, que vão virar óleos, cremes, sabonetes, perfumes em indústria de cosméticos na Grande São Paulo.

Por ser exibido no domingo de manhã, o programa procura ter esse tom mais otimista, trazendo matérias positivas e retratando aquilo que deu certo. "A leitura que você tem no final de um programa é que as coisas vão bem, o país tem problemas, mas também tem um monte de gente buscando soluções, trabalhando, criando, atuando", afirma Gabriel Prioli, crítico de TV, diretor da TV PUC e presidente da Associação Brasileira de TVs Universitárias (ABTU). 
O programa, portanto, tem um perfil edificante, que alegra, estimula e serve de inspiração para quem está vendo, além de fazer uma prestação de serviços na medida em que auxilia muitos brasileiros a se mobilizarem em associações, a descobrirem as vias pelas quais reclamar seus direitos, a visualizarem uma possibilidade de solução para seus problemas.

Algumas vezes, essa prestação de serviços não tem resultados tão imediatos. Por exemplo, de entender melhor como funciona a natureza, já que o meio rural é o grande responsável pelo meio ambiente, e de democratizaro acesso à informação pertinente ao homem do campo, em um país de desigualdades tão brutais que acabam até inviabilizando a sobrevivência do pequeno produtor e da agricultura familiar.

Mas a maior prestação de serviços fica por conta da resposta das cartas. Chegam, em média, 50 correspondências por dia à redação, quantidade que aumenta quando determinado assunto suscita muita curiosidade. A grande maioria pede informações sobre determinada cultura ou criação, alguma praga ou doença - mas há também quem escreva só para contar sobre a vida. De todas as correspondências, algumas são selecionadas e arquivadas na redação, para serem respondidas no programa de domingo. Algumas dão origem a matérias e outras são respondidas no próprio estúdio,com a indicação de algum material impresso sobre o assunto ou com base nas informações dos consultores do Globo Rural.

Todas são respondidas via correio, em papel timbrado da Rede Globo, contendo o endereço de algumas instituições em que o telespectador pode encontrar informações especializadas sobre o assunto que o motivou a escrever. São circulares que a equipe elaborou ao longo do tempo, com respostas-padrão sobre os assuntos mais procurados - abelha, laranja, café, coelho, etc. Quando um novo assunto se torna alvo de grande procura - o amendoim forrageiro, por exemplo-, uma nova circular é preparada.

Cuidar dessa correspondência deve ser trabalho duro por conta da quantidade de cartas que chegam diariamente para o CEP 04583-905. Mas, certamente, é tarefa agradável e gratificante, pois permite ler muitos elogios ao programa; receber muitos votos de saúde, paz e prosperidade; descobrir o que têm a dizer pessoas de todo o Brasil, desde a que digita seu texto no computador até a outra que mal consegue traçar sua caligrafia num pedacinho de folha de caderno, ou aquela que enfeita o papel com flores coloridas de biscuit ou uvas brilhantes de glitter.

Muitas pessoas se intitulam "assistentes", "videntes" e "ouvintes" do programa. A linguagem chama a atenção não tanto por ser simples, nem pela caligrafia, que indica dificuldade para traçar as letras, nem pelos erros de português, mas sim pelo jeito como as pessoas se referem ao programa e à equipe e pela proximidade e carinho que transmitem. "Nos primeiros parágrafos as pessoas escrevem pra gente dando bom dia, perguntando como vai a saúde, mandando paz, como se já nos conhecessem", explica Dassie.

A tarefa de abrir as correspondências do Globo Rural pode ser uma aventura, principalmente aquelas que, só pelo tamanho e peso, já indicam que ali vem mais coisa do que um papel com palavras. Chegam sedex, fitas de vídeo, fotos, sementes, folhas, formigas, barata, escorpião, frutas, etc. Há também o lado emocionante de ler sobre os sonhos e as necessidades daqueles que pedem um emprego de caseiro no sítio, um emprego de engenheiro agrônomo, um cavalo, um pedacinho de terra, uma bicicleta, um videogame.

\section{NARRATIVAS DO SER HUMANO}

Em vez de contar a história de uma forma mais fria, "objetiva”, por meio da técnica ou de conceitos abstratos, o programa optou por entrar na realidade abordada a partir dos dramas humanos, tendo o ser humano como eixo e fio condutor da narrativa, valorizando as pessoas que constroem o mundo rural, seja o homem do campo, o 
índio, o agrônomo, o veterinário, o pesquisador. Muitas vezes a reportagem constrói um perfil do personagem, do protagonista, quer seja o poeta Patativa do Assaré ou mesmo uma árvore, como o jacarandá, o jequitibá ou o pau-brasil, que ganham status de personagem em reportagens especiais.

A equipe brinca que tem como lema “Nosso herói é o agricultor", sendo esse "agricultor", na verdade, o habitante da pequena cidade e o homem do campo, de forma geral. Na maioria dos casos, ele é o personagem da reportagem e não o ministro da Agricultura ou o diretor da Embrapa, nem outras fontes oficiais ou acadêmicas Esses só costumam aparecer em entrevista prestando contas de seus serviços para o homem do campo, seja esclarecendo uma dúvida técnica ou divulgando um novo programa do governo. Quem importa é o homem do campo. "É ele que tem que aparecer no programa, é ele que tem que dizer o que ele acha da vida, ele que tem que fazer as reclamações, ele tem que dar as risadas dele, ele tem que chorar, ele tem que acontecer. E se ele tem uma cobrança a fazer, aí o poder público entra", explica o chefe de redação, Gabriel Romeiro.

Com essa prática de trocar as fontes oficiais por brasileiros anônimos, descobertos por meio das cartas ou durante o próprio trabalho de campo, o Globo Rural acaba dando voz a um pedaço da população que não tem voz e também mostrando uma gente que não se vê na televisão - ou que se vê pouco e, muitas vezes, de forma preconceituosa, com um olhar urbano, sem merecer um tratamento específico.

Não há um "monopólio da fala" - referência à expressão criada por Muniz Sodré (1977) para definir uma característica intrínseca dos meios massivos - nem a "nãocomunicação", porque o programa abre espaços para tentativas de diálogos e de interação entre os diferentes atores do mundo rural (10). Cria-se um "plurálogo" (11).

Seja tratando de pesquisas científicas ou medidas econômicas e políticas, a idéia é tentar trazer essas questões para a vida do cidadão. Por exemplo, se há uma notícia sobre o aumento na exportação de sucos para a Europa, é preciso verificar se isso está chegando até o produtor de laranja, se aumentaram suas vendas e lucros. Ou, então, no caso dos transgênicos, é preciso abordar que efeitos têm na produção, o que isso afeta em sua vida e como ele vai se beneficiar ou não com o uso dessa tecnologia.

Outra característica é a valorização do regionalismo, pois cada região do Brasil tem um sotaque, um palavreado, uma expressão, um jeito, os quais o Globo Rural consegue mostrar na voz e na figura de tantos personagens brasileiros, além de incorporar um pouco dessa riqueza e diversidade em sua própria linguagem. "A gente acaba assumindo algumas coisas do linguajar regional, que é diferente de região pra região também. Regionalismo para nós é qualidade e riqueza cultural. Cada brasileiro tem um sotaque, tem um jeito, tem um ritmo, tem um batuque e isso é rico, isso é bacana de pôr no programa", explica o repórter Vico Iasi.

O elemento humano e a maneira como ele se relaciona com a realidade sempre imperaram na linha narrativa das reportagens do Globo Rural. A busca do programa não é simplesmente por um entrevistado que saiba tratar de um assunto, mas, preferencialmente, por uma pessoa que tenha uma relação intensa com o assunto ou que seja apaixonada por aquilo, uma pessoa que pode se transformar de fonte em personagem e enriquecer a narrativa. "A gente vai encontrar um pesquisador que é um apaixonado por aquele setore que daí você acaba compondo uma reportagem através da visão desse técnico ou desse cientista", explica Battaglin.

Quando uma reportagem consegue captar intensamente toda a expressão de um ser humano, quando consegue encontrar uma pessoa que fala sobre sua vida e seu trabalho com brilho nos olhos, o resultado é perceptível para o público. Para o repórter José Hamilton Ribeiro, isso engrandece a reportagem: "Toda vez que você está fazendo uma reportagem e esbarra num ser humano que tenha brilho nos olhos, que
10 Luís Carlos Ferreira de Souza Oliveira, "O Programa 'Glo bo Rural' na Região Sul do Estado de Minas Gerais - un Estudo de Caso", in Revista Brasileira de Comunicação anoXI, n. 59, jul.-dez./1988 pp. 17-33

11 Cremilda Medina, Entrevisto: O Diálogo Possivel, op. cit. p. 18 
fala com esperança, que fala com entusiasmo, quando você consegue que os seus entrevistados sejam autênticos, que eles revelem aquela pureza, aquela certeza que cada um tem com o que faz quando gosta de fazer, ou, então, do outro lado, quando está fazendo uma denúncia, quando está fazendo uma crítica, você pega a pessoa num flagrante, você pega a vida em flagrante, você consegue chegar no personagem na hora que ele quer falar, que ele tem uma coisa pra dizer, isso cresce na televisão".

Portanto, nada melhor do que encontrar personagens com expressividade. Para Ribeiro, não são, necessariamente, pessoas "falantes", porque uma pessoa pode falar muito, mas só falar bobagens. São pessoas capazes de expressar sua realidade de uma maneira muito significativa, “às vezes com um sorriso, às vezes com uma palavra, com um gesto".

Para o repórter e apresentador Nelson Araújo, o fato de o veículo permitir que se divulguem tantas informações, além do próprio texto, é uma grande qualidade da televisão: "Um minuto de televisão, dois minutos, cinco minutos é uma carga de informação espetacular. Porque você tem imagens, você tem som, você tem cor, você tem música, você tem a palavra, você tem op. cit., p. 18 o sotaque, você tem o gesto. São várias linguagens sobrepostas. Por menor que seja, isso que o pessoal fala 'não aprofundou', como não aprofundou? Você viu a mulher chorando, você viu a pessoa falando, você viu o sotaque, você viu isso, tudo informação".

A situação de estar em frente a uma câmera costuma ser sempre intimidatória, principalmente para aqueles que não estão acostumados. Algumas pessoas "travam", outras gaguejam, outras ficam sérias, outras não param de rir, outras "vestem uma máscara”. "A entrevista, evidentemente, se funda na mais duvidosa e mais rica das fontes, a palavra. Ela corre o risco permanente de dissimulação ou da fabulação", segundo Edgar Morin (12).

Portanto,é preciso muito esforço e sensibilidade da equipe para deixar o entrevistado à vontade, apesar da agressão daquele equipamento todo. O resultado no vídeo transparece que a equipe conseguiu fazer a câmera interferir o menos possível na cena, de modo que o entrevistado até parece que esqueceu a presença do equipamento e conseguiu se expressar com naturalidade.

O Globo Rural tem a vantagem de, às vezes, ficar vários dias em contato com os entrevistados, numa convivência que traz um pouco mais de intimidade e confiança. "A gente vai brincando, vai se enturmando e eles passam a fazer parte da equipe. Então, já se soltam um pouco mais", conta o repórter-cinematográfico Francisco Maffezoli Jr.

Além disso, há mais tempo para as gravações, diferente dos telejornais diários, em que o repórter mobiliza céu e terra para conseguir um entrevistado que se encaixe na matéria (por exemplo, uma dona de casa reclamando do aumento de preços no supermercado), grava a entrevista sem muito tempo e a fita ainda tem que ser levada de motoboy até a emissora, para a matéria ser editada e exibida no mesmo dia. Nesse ritmo frenético, é bem mais complicado estabelecer relações com os entrevistados.

No caso do Globo Rural, a situação é mais favorável. Para a produtora de reportagens Ana Castro, acaba sendo até uma 
relação menos consumista já que, muitas vezes, a equipe passa muitos dias com essas pessoas e, depois, na medida do possível, mantém o contato, avisa quando a matéria vai ser exibida, providencia uma cópia do material quando solicitado.

Alguns não têm dúvida também de que a receptividade seja muito maior no campo e nas pequenas cidades. "Você pára numa cidadezinha para fazer uma imagem de um caminhão coletando lixo passando, aí a senhora que não tem nada a ver com a reportagem, que mora em frente, te convida pra tomar café, comer pão de queijo", conta Junior.

\section{UM BOM-DIA PRA VOCÊ!}

Todos esses elementos elencados até aqui contribuem para criar uma empatia com a fonte e com o telespectador. O povo brasileiro se vê no Globo Rural. Se vê, se identifica, se reconhece, aprende, tira dúvidas, se revolta, se emociona. "Um leitor, ouvinte ou telespectador sente quando determinada entrevista passa emoção, autenticidade, tanto no discurso enunciado pelo entrevistado quanto no encaminhamento das perguntas pelo entrevistador. Ocorre, com limpidez, o fenômeno da identificação, ou seja, os três envolvidos (fonte de informação-repórter-receptor) se interligam numa única vivência. A experiência de vida, o conceito, a dúvida ou o juízo de valor do entrevistado transformam-se numa pequena ou grande história que decola do indivíduo que narra para se consubstanciar em muitas interpretações. A audiência recebe os impulsos do entrevistado, que passam pela motivação desencadeada pelo entrevistador, e vai se humanizar, generalizar no grande rio da comunicação anônima. Isto, se a entrevista se aproximou do diálogo interativo" (13).

Segundo o chefe de reportagem, Lucas Battaglin, essa identificação com o programa atinge desde o trabalhador sem-terra até o grande fazendeiro. "Eu acho que as pessoas são bem tratadas pelo Globo $R u$ - ral, a gente tem uma relação com as pessoas muito boa. Porque toda vez que a gente vai falar com o grande fazendeiro ou com o sem-terra é com o maior respeito, com aquela intensidade. Eu acho que o sem-terra quando vê o Globo Rural, ele se reconhece. E o grande fazendeiro quando vê o Globo Rural, ele se reconhece."

Evidentemente, esses elementos e qualidades não estão presentes no programa todo nem em $100 \%$ das reportagens, pois assim é o jornalismo. Nunca há um trabalho plenamente satisfatório, é impossível fazer todas as edições saírem geniais, é um desafio permanente para tornar o trabalho menos vulnerável e imperfeito, uma labuta diária para ultrapassar as imperfeições de cada dia, uma luta nova a cada edição.

Mas existe essa busca constante e coletiva no Globo Rural, levada adiante por profissionais do jornalismo que, convivendo dentro de uma equipe tão estável, de um clima amistoso na redação, acreditam no valor de sua profissão e na possibilidade de concretização de seu papel social. Dedicam-se de corpo e alma ao trabalho, com esforço profissional (e até físico) e muita sensibilidade, porque acreditam no que estão fazendo. Assim, tecem as narrativas da contemporaneidade de mãos dadas com o mundo rural e entram na casa de milhões de brasileiros todo domingo às 8 da manhã .

Para Battaglin, o trabalho, a dedicação e o carinho com que eles preparam o programa passam para o público: "Esse carinho que a gente tem por esse público acaba passando em cada linha do programa que a gente faz. Não tem uma pessoa que esteja aqui, ou se tiver é uma minoria ínfima assim, todo mundo que você vai encontrar aqui está aqui porque gosta da temática, gosta do jeito de fazer".

“Às vezes a gente até se arrebenta, mas você vai movido pelo ideal da matéria mesmo. Se arrebenta mesmo, você fica no meio do mato, em lugares que você não deveria estar ali, daquele jeito. Mas é você mesmo quem vai, é muito mais do que te pede a empresa ou o programa, é pelo teu envolvimento pessoal com teu ideal", conta o repórter Vico Iasi.
3 Cremilda Medina, Entrevista: O Diálogo Possível, op. cit, pp. 5-6. 